\title{
DIVERSIFIKASI PRODUK UNGGULAN DAERAH BAWANG MERAH LOKAL KHAS NGANJUK UNTUK MENCIPTAKAN EKONOMI KREATIF
}

\author{
Oleh: \\ Fauziyah $^{1}$, Tri Handayani², Riswan Eko Wahyu S³., Aulia Dewi Rosanti ${ }^{4}$ \\ Universitas Islam Kadiri \\ fauziyah@uniska-kediri.ac.id
}

\begin{abstract}
Nganjuk dikenal sebagai surganya bawang merah di Jawa Timur. Sentra penananam bawang merah di Kabupaten Nganjuk berada, kec. Sukomoro, kec. Rejoso, Kec. Gondang, Bagor, dan Wilangan. Kegiatan ini merupakan kegiatan PPUD tahun Ke dua yang dilaksanakan di Kec. Sukomoro Kab. Nganjuk. Pelaksanaan kegiatan berfokus pada pengembangan produk olahan bawang merah dan pemasaran produk olahannya. Metode yang dilakukan dengan subsitusi teknologi tepat guna kepada mitra dan juga pendampingan teknologi pengolahan dan pemasaran olahan produk bawang merah. Hasil dari kegiatan PPPUD tahun kedua ini antara lain: (1) Pengembangan teknologi mesin pencuci dan perajang bawang merah kapasitas besar, (2) Pendampingan dalam kegiatan jasa, Pengurusan merek dagang, (3) Pelatihan produk diversifikasi bawang merah, (4) Pengurusan legalitas produk, (5) Pembuatan label produk, (6) Membuat strategi bisnis. Diperoleh peningkatan kualitas produk sebesar $70 \%$, peningkatan kapasitas produksi sebesar $90 \%$, peningkatan Omzet $80 \%$, peningkatan luas pasar $60 \%$, peningkatan jumlah tenaga kerja $200 \%$, peningkatan jenis produk $200 \%$, peningkatan nilai aset $90 \%$. Serta peningkatan jenis produk diversifikasi yang baru dihasilkan ditahun ke-2 diantaranya aroma/parfume bawang, roti berbahan abon bawang, serta kue berbahan aroma bawang.
\end{abstract}

Kata kunci: Bawang merah, Teknologi, Produk, Olahan, Diversifikasi

\begin{abstract}
Nganjuk is known as the paradise of shallots in East Java. The onion growing center in Nganjuk Regency is located, sub-district. Sukomoro, Rejoso, Gondang, Bagor, and Wilangan. This activity is the second year PPUD activity held in sub-district Sukomoro, district Nganjuk. The implementation of activities focuses on developing processed shallot products and marketing the processed products. The method is carried out by substituting appropriate technology for partners and also assisting processing technology and marketing of processed shallot products. The results of this second year PPPUD activities include: (1) Development of large capacity washing machine and shallot chopper technology, (2) Assistance in service activities, management of trademarks, (3) training on onion diversification products, (4) legality management products, (5) making product labels, (6) creating a business strategy. Obtained an increase in product quality by $70 \%$, an increase in production capacity by $90 \%$, an increase in turnover of $80 \%$, an increase in market area of $60 \%$, an increase in the number of workers $200 \%$, an increase in product types $200 \%$, an increase in asset value $90 \%$. As well as an increase in the types of diversified products that have just been produced in the 2nd year, including onion fragrance/perfume, bread made from shredded onions, and cakes made from onion aroma.
\end{abstract}

Keywords: Shallots, Technology, Products, Processed, Diversification

\section{PENDAHULUAN}

Nganjuk dikenal sebagai surganya bawang merah di Jawa Timur. Julukan ini memang sangat sesuai dengan kondisi kabupaten Nganjuk yang menghasilkan bawang merah yang melimpah. Yang merupakan manisvestasi kearifan lokal yang terdapat dikabupaten Nganjuk. Sentra penananam bawang merah di Kabupaten Nganjuk berada di lima kecamatan, yaitu Sukomoro, Rejoso, Gondang, Bagor, dan Wilangan. Total area penanaman bawang merah mencapai $11.300 \mathrm{Ha}$, dengan jumlah petani sebanyak 9.709 orang. (Deptan Nganjuk, 2017).

Berdasarkan penelitian/kegiatan terdahulu dapat ditunjukkan dalam state of the Art, tabel 1 berikut; 
Tabel 1. State of The Art

\begin{tabular}{|c|c|c|c|c|c|c|}
\hline No. & $\begin{array}{l}\text { Nama } \\
\text { peneliti }\end{array}$ & $\begin{array}{l}\text { Tahun, } \\
\text { Penerbit, } \\
\text { Judul } \\
\text { artikel }\end{array}$ & Kesimpulan & $\begin{array}{l}\text { Handayanı, } \\
\text { Susanto, } \\
\text { Rosanti }\end{array}$ & $\begin{array}{l}\text { "Diversifikasi } \\
\text { Produk } \\
\text { Unggulan } \\
\text { Daerah }\end{array}$ & $\begin{array}{l}\text { dllakukan } \\
\text { kegiatan PKM } \\
\text { PPUD Nganjuk } \\
\text { yang berupa } \\
\text { Olahan Bawang }\end{array}$ \\
\hline 1 & $\begin{array}{l}\text { Fauziyah, } \\
\text { Handayani, } \\
\text { Susanto, } \\
\text { Rosanti }\end{array}$ & $\begin{array}{l}\text { 2019, } \\
\text { Indomedia } \\
\text { Pustaka, } \\
\text { "Aneka } \\
\text { Produk } \\
\text { Olahan } \\
\text { Bawan } \\
\text { Merah" }\end{array}$ & $\begin{array}{l}\text { Dengan adanya } \\
\text { program PPPUD } \\
\text { akan menciptakan } \\
\text { teknologi } \\
\text { pengolahan } \\
\text { bawang merah } \\
\text { menjadi produk } \\
\text { unggulan olahan } \\
\text { bawang merah } \\
\text { lokal di kabupaten } \\
\text { Nganjuk. } \\
\text { Sehingga Nganjuk } \\
\text { sebagai penghasil } \\
\text { Produk Unggulan } \\
\text { Daerah dari Hulu } \\
\text { hingga Hilir }\end{array}$ & & $\begin{array}{l}\text { bawang } \\
\text { Merah Lokal } \\
\text { Khas } \\
\text { Nganjuk } \\
\text { untuk } \\
\text { meningkatka } \\
\text { n UMKM" }\end{array}$ & $\begin{array}{l}\text { Merah Lokal } \\
\text { Khas Nganjuk } \\
\text { produk seperti } \\
\text { Bawang goreng } \\
\text { nabati/herbal, } \\
\text { pasta bawang } \\
\text { merah, krupuk } \\
\text { bawang warna } \\
\text { alami dari rempah } \\
\text { (pandan, buah } \\
\text { naga dan kunyit). } \\
\text { Produk olahan ini } \\
\text { merupakan } \\
\text { produk unggulan } \\
\text { dari bawang } \\
\text { merah Nganjuk }\end{array}$ \\
\hline 2 & $\begin{array}{l}\text { Fauziyah, } \\
\text { Handayani, } \\
\text { Susanto, } \\
\text { Rosanti }\end{array}$ & $\begin{array}{l}2020, \\
\text { ABDI, } \\
\text { "Pengolahan } \\
\text { Produk } \\
\text { Unggulan } \\
\text { Daerah } \\
\text { Bawang } \\
\text { Merah Lokal } \\
\text { di Kec. } \\
\text { Sukomoro } \\
\text { Kab. } \\
\text { Nganjuk" }\end{array}$ & $\begin{array}{l}\text { Hasil yang telah4. } \\
\text { dicapai pada } \\
\text { tahun pertama } \\
\text { program PPPUD } \\
\text { ini antara lain: } \\
\text { (1)Pembuatan } \\
\text { peralatan } \\
\text { teknologi } \\
\text { pengolahan } \\
\text { bawang merah } \\
\text { dan penyerahan } \\
\text { kepada mitra, } \\
\text { (2)Pengolahan } \\
\text { produk bawang } \\
\text { merah, (3) merk } \\
\text { dagang (4) } \\
\text { Peningkatan } \\
\text { omset dan tenaga } \\
\text { kerja yang dimiliki }\end{array}$ & $\begin{array}{l}\text { Resmi, } \\
\text { dkk., }\end{array}$ & $\begin{array}{l}2017, \text { ANDI, } \\
\text { "Parfum } \\
\text { Bawang } \\
\text { Merah dan } \\
\text { Aneka } \\
\text { Produk } \\
\text { Olahan } \\
\text { Bawang } \\
\text { Merah" }\end{array}$ & $\begin{array}{l}\text { Bahwa bawang } \\
\text { merah bisa } \\
\text { dijadikan sebagai } \\
\text { parfum ruangan } \\
\text { yang fungsinya } \\
\text { untuk } \\
\text { menghilangkan } \\
\text { aroma. Selain itu } \\
\text { dapat } \\
\text { dimanfaatkan } \\
\text { untuk mengusir } \\
\text { hewan } \\
\text { penganggu, } \\
\text { sebagai pengganti } \\
\text { obat pestisida } \\
\text { yang aman dan } \\
\text { murah dan tidak } \\
\text { berbahaya bagi } \\
\text { kesehatan. }\end{array}$ \\
\hline & & & $\begin{array}{l}\text { oleh mitra, }(\overline{5} 5 \\
\text { Penggunaan } \\
\text { media pemasaran } \\
\text { online. }\end{array}$ & $\begin{array}{l}\text { Susanto } \\
\text { REW, dkk }\end{array}$ & $\begin{array}{l}2020, \\
\text { SNASPPM, } \\
\text { "Diversifikasi } \\
\text { Produk }\end{array}$ & $\begin{array}{l}\text { Penerapan } \\
\text { teknologi proses } \\
\text { pemotongan daun } \\
\text { bawang diperoleh }\end{array}$ \\
\hline & & & & & $\begin{array}{l}\text { Unggulan } \\
\text { Daerah } \\
\text { bawang } \\
\text { Merah Lokal } \\
\text { Khas } \\
\text { Nganjuk } \\
\text { untuk } \\
\text { meningkatka } \\
\text { n UMKM" }\end{array}$ & $\begin{array}{l}\text { hasil diantaranya; } \\
\text { penggunaan } \\
\text { teknologi semi } \\
\text { otomasi, waktu } \\
\text { pemotongan lebih } \\
\text { cepat } 10 \text { menit, } \\
\text { biaya operasional } \\
\text { yang dikeluarkan } \\
\text { lebih hemat, dan } \\
\text { penggunaan daya } \\
\text { energi lebih } \\
\text { murah. Sehingga } \\
\text { penerapan } \\
\text { teknologi } \\
\text { memberikan } \\
\text { manfaat, efektifi } \\
\text { dan efisiensi } \\
\text { waktu dan biaya } \\
\text { operasional }\end{array}$ \\
\hline
\end{tabular}




\begin{tabular}{|c|c|c|c|}
\hline 6 & $\begin{array}{l}\text { Perdana } \\
\text { Putra Z., } \\
\text { dkk, }\end{array}$ & $\begin{array}{l}\text { 2018, } \\
\text { AGROINDU } \\
\text { STRI, } \\
\text { "Analisis } \\
\text { Nilai } \\
\text { Tambah } \\
\text { Bawang } \\
\text { Goreng } \\
\text { pada } \\
\text { UDSafari } \\
\text { bawang Di } \\
\text { Kebun } \\
\text { Tebeng } \\
\text { Kota } \\
\text { Bengkulu" }\end{array}$ & $\begin{array}{l}\text { Pengolahan } \\
\text { bawang menjadi } \\
\text { bawang goreng } \\
\text { terdiri dari } \\
\text { beberapa tahap } \\
\text { diantananya } \\
\text { bahan baku, } \\
\text { pemolenan, } \\
\text { penyortiran, } \\
\text { pengirisan, } \\
\text { pembubuhan } \\
\text { dengan tepung, } \\
\text { penggorengan, } \\
\text { pengepresan, } \\
\text { pengemasan. } \\
\text { Nilai tambah yang } \\
\text { diperoleh dalam } \\
\text { penelitian ini } \\
\text { adalah Rp } \\
\text { 9549.65/ kg BB. }\end{array}$ \\
\hline 7 & $\begin{array}{l}\text { Arfinanti } \\
\text { Nurul }\end{array}$ & $\begin{array}{l}2019, \\
\text { APLIKASIA, } \\
\text { "Upaya } \\
\text { peningkatan } \\
\text { Nilai } \\
\text { Tambah } \\
\text { produk } \\
\text { Bawang } \\
\text { Merah" }\end{array}$ & $\begin{array}{l}\text { Terciptanya } \\
\text { Produk olahan } \\
\text { bawang merah } \\
\text { dengan varian } \\
\text { tempe, kentang, } \\
\text { dll. Dan bawang } \\
\text { merah aneka rasa } \\
\text { serta terdapat nilai } \\
\text { tambah yang } \\
\text { signifikan dan } \\
\text { keuntungan. }\end{array}$ \\
\hline 8. & $\begin{array}{l}\text { Indrawati } \\
\text { E.M., dkk, } \\
2020 \text {, }\end{array}$ & $\begin{array}{l}\text { 2020, } \\
\text { ABDINUS, } \\
\text { "Pelatihan } \\
\text { Pengolahan } \\
\text { Bawang } \\
\text { dengan Alat } \\
\text { Pebmo } \\
\text { Pada } \\
\text { Kelompok } \\
\text { Petani } \\
\text { Bawang } \\
\text { Merah Desa } \\
\text { Sekoto Kab. } \\
\text { Kediri" }\end{array}$ & $\begin{array}{l}\text { Kegiatan } \\
\text { pengabdian } \\
\text { kepada } \\
\text { Masyarakat } \\
\text { dengan } \\
\text { menggunakan alat } \\
\text { (PEBMO) kepada } \\
\text { petani bawang } \\
\text { merah bermanfaat } \\
\text { untuk } \\
\text { meningkatkan } \\
\text { penghasilan } \\
\text { petani bawang } \\
\text { merah }\end{array}$ \\
\hline
\end{tabular}

Dalam kegiatan ini tujuan yang akan dicapai sebagai indikator capaian yaitu adanya peningkatan dan pengembangan pada produk olahan bawang merah, sehingga akan memberikan penambahan / peningkatan pendapatan yang dapat memberikan manfaat daerah nganjuk khususnya kecamatan sukomoro.

\section{METODE PELAKSANAAN}

Kegiatan PPPUD pada tahun ke 2 ini dilaksanakan pada bulan Mei sampai dengan September 2020. Lokasi yang menjadi mitra PPPUD adalah di desa Ngrami, Kecamatan Sukomoro, Kabupaten Nganjuk.

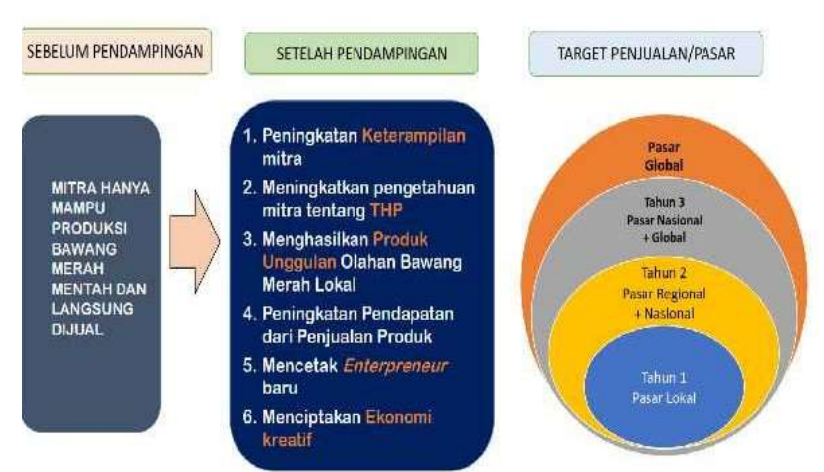

Gambar 1. Metode Pendampingan produksi dan pemasaran

Pelaksanaan kegiatan berfokus pada pengembangan produk olahan bawang merah dan pemasaran produk olahannya. Metode yang dilakukan dengan "subsitusi teknologi tepat guna" kepada mitra dan juga pendampingan teknologi pengolahan dan pemasaran olahan produk bawang merah. Adapun Gambaran metode pelaksanan program yang telah dilakukan dalam tahun ke 2 ini disajikan dalam Gambar 1 diatas.

\section{HASIL DAN PEMBAHASAN}

Dalam kegiatan Pengabdian Kepada Masyarakat PPPUD tahun kedua ini telah dilaksanakan beberapa kegiatan yang telah dilaksanakan, diantaranya: untuk menunjang produksi mitra maka perlu adanya pengembangan Teknologi Mesin pengolah produk bawang merah (mesin pencuci dan perajang bawang merah) dengan kapasitas yang lebih besar, serta memberikan pendampingan dalam proses pengoperasian mesin tersebut, pada gambar berikut memperlihatkan pengembangan dari mesin diantaranya mesin perajang bawang merah, mesin pembersih bawang merah, serta freezer tempat penyimpanan hasil rajanangan bawang merah agar bawang tidak mudah membusuk, dan dapat diolah menjadi olahan bawang sesuai dengan waktu yang diinginkan.

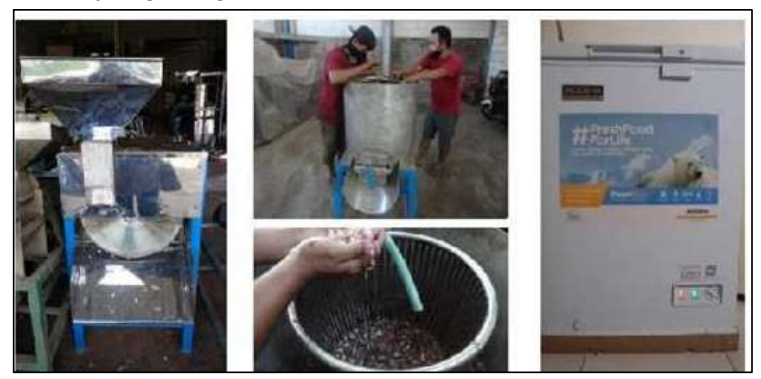

Gambar 2. Pendampingan penggunaan mesin produksi bawang 
Kemudian dilanjutkan dengan pendampingan dan pembinaan tentang manajemen produksi yaitu: cara membuat layout produksi, perencanaan produk, membuat desain produk, menentukan biaya produk, melakukan pengujian produk, mengawasi produk, memelihara sarana dan prasarana fasilitas produksi seperti mesin dan peralatan penunjang lainnya. Dalam gambar 3 ditunjukkan alur kerja layout proses produksi yang dilengkapi dengan mesin pengolahan secara "line production".

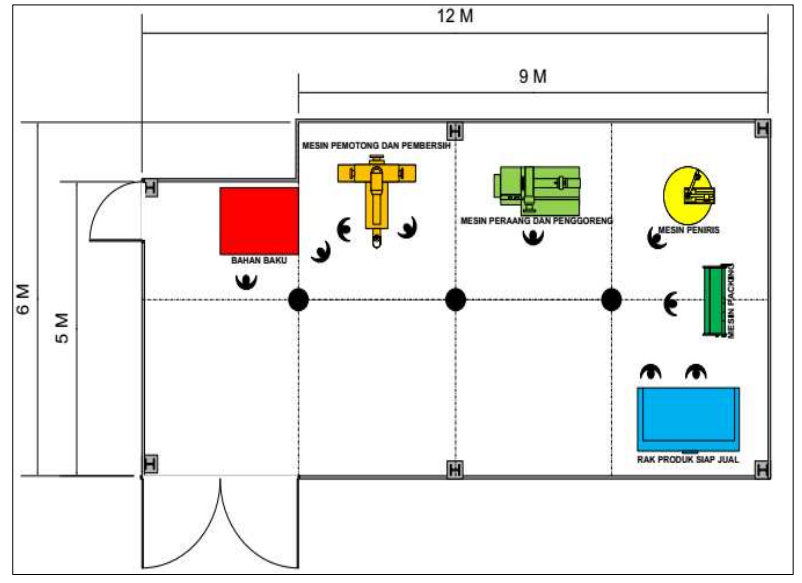

Gambar 3. Perencanaan Layout Produksi

Dalam hasil pengujian analisis kelayakan kandungan produk olahan bawang merah yang diuji di dinas pangan (lab.kimia) diperoleh data sebagai berikut:

Tabel 2. Hasil Analisis Uji Proksimat/Komposisi Produk

\begin{tabular}{|c|c|c|c|c|c|c|}
\hline \multirow[b]{2}{*}{ Produk } & \multicolumn{6}{|c|}{ Kadar (\%) } \\
\hline & Air & Protein & Lemak & Vit.C & Serat & $\begin{array}{l}\text { Karbo } \\
\text { hidrat }\end{array}$ \\
\hline $\begin{array}{l}\text { Bawang Goreng } \\
\text { Merah tanpa } \\
\text { Tepung } \\
\end{array}$ & 5,0 & 8,09 & 28,64 & 1,69 & - & - \\
\hline $\begin{array}{l}\text { Bawang Goreng } \\
\text { Merah dengan } \\
\text { Tepung }\end{array}$ & 5,61 & 9,57 & 23,26 & 1,71 & - & - \\
\hline $\begin{array}{l}\text { Pasta Bawang } \\
\text { Merah }\end{array}$ & $\begin{array}{c}76,3 \\
4\end{array}$ & 4,46 & 18,26 & - & - & - \\
\hline $\begin{array}{l}\text { Kerupuk Bawang } \\
\text { Merah } \\
\text { Pelangi }\end{array}$ & 5,32 & 7,03 & 25,18 & - & - & - \\
\hline $\begin{array}{l}\text { Tepung Bawang } \\
\text { Merah }\end{array}$ & $\begin{array}{c}13,4 \\
0\end{array}$ & 9,32 & 2,22 & - & 6,17 & 51,6 \\
\hline
\end{tabular}

Dimana pada tabel 2. diatas tepung bawang merah memiliki kandungan yang sama dengan produk lain (bawang goreng, pasta, dan kerupuk) tetapi memiliki kandungan lain yang muncul yaitu kadar serat $6,17 \%$ dan karbohidrat $51,6 \%$.

Kegiatan lain berupa pendampingan kepada SDM yaitu : memberikan pelatihan teknologi hasil pascapanen, membuat produk olahan bawang merah, memberikan keterampilan membuat produk unggulan, melatih disiplin kerja, memberikan tanggung jawab sebagai wirausaha. Mulai dari pendampingan pemasaran produk ,penggunaan aplikasi pemasaran secara ECommerce dan menentukan strategi pemasaran yang tepat, serta pendampingan kepada mitra dibidang manajemen keuangan dan sistem akuntansi yaitu : Melatih mengelola keuangan perusahaan, membuat laporan keuangan, Neraca, Laba/Rugi, Arus Kas dan menganalisis laporan keuangan. Gambar 4 dibawah mennujukkan proses pendampingan oleh tim pelaksana yang terdiri dari dosen dan mahasiswa dalam proses pengemasan hasil olahan yang akan di pasarkan.

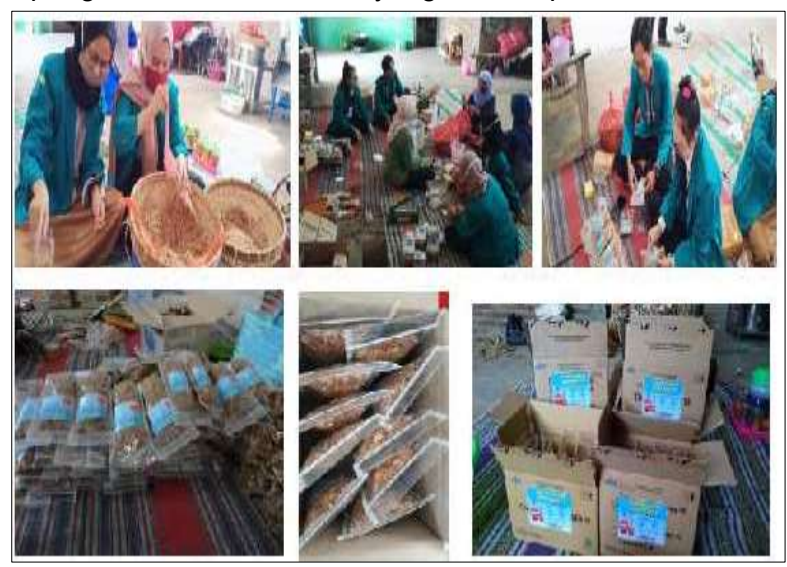

Gambar 4. Pendampingan pengemasan Produk rencanaan Layout Produksi

Dan kegiatan lain terkait legalitas usaha dengan mendampingi dalam pengurusan merk usaha "SUKOMORO", ijin usaha PIRT untuk mendapatkan legalitas produk dari Dinas Kesehatan, pengurusan sertifikasi produk ke Badan Pengobatan Obat-obatan dan Makanan (BPOM), pengurusan sertifikasi produk untuk mendapatkan sertifikasi produk Halal dari MUI. Gambar 4 menunjukkan gambar merk yang telah terdaftar di HKI sebagai merek dagang sah.

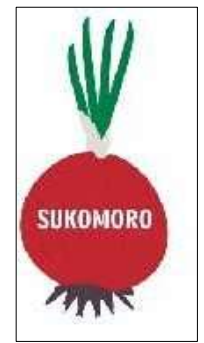


Gambar 5. Merek Produk yang sudah terdaftar di HKI

Dalam kegiatan PPUD bawang merah ditahun kedua ini terdapat beberapa penngkatan kuantitas dan kualitas pelaksanaan yang dapat dibandingkan dengan tahun sebelumnya, diantaranya: Terkait pengembangan fasilitas produksi tempat uasaha mitra telah meningkat sebagaimana ditunjukkan dalam gambar 6 . Dengan luasan tempat usaha lebar $6 \mathrm{~m}$ dan panjang 12 meter yang sesuai dengan lay out pada gambar 3 diatas ,

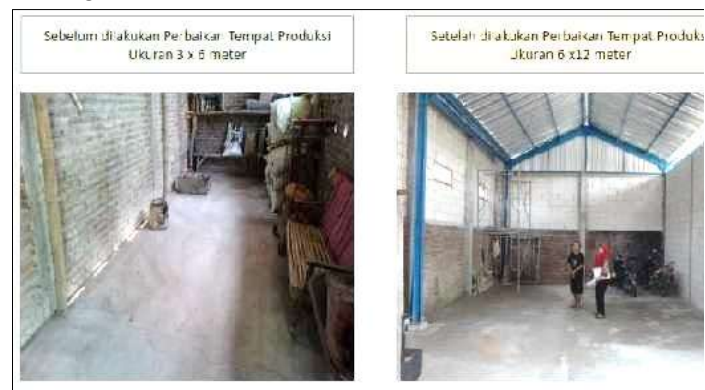

Gambar 6. Tempat produksi tahun pertama dan tahun kedua

Kemudian kegiatan penambahan mesin produksi dari tahun sebelumnya yang ditunjukkan dalam gambar 7., dimana pada gambar 7 menjelaskan tentang perbedaan serta peningkatan proses produksi antara tahun pertama (2019) dan tahun kedua (2020), yang telah banyak menggunakan teknologi/mesin pengolahan, mulai dari mesin-mesin bawang goreng, mesin pengolah pasta bawang, mesin pengolah tepung, dan mesin-mesin pengemasan dengan skala produksi yang besar.

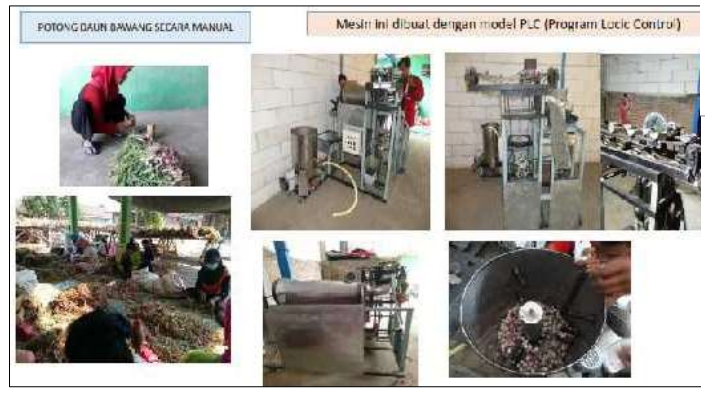

Gambar 7. Proses produksi tahun pertama dan tahun kedua yang menggunakan pengembangan mesin

Dalam rangka peningkatan hasil omzet maka tim pelaksana pengabdian telah membuka outletoutlet pemasaran guna membantu mitra dalam penjualan produk hasil olahan sebagaimana ditunjukkan pada gambar 8 dibawah ini, yang memperlihatkan outlet pemasaran serta tim pelaksana pengabdian.

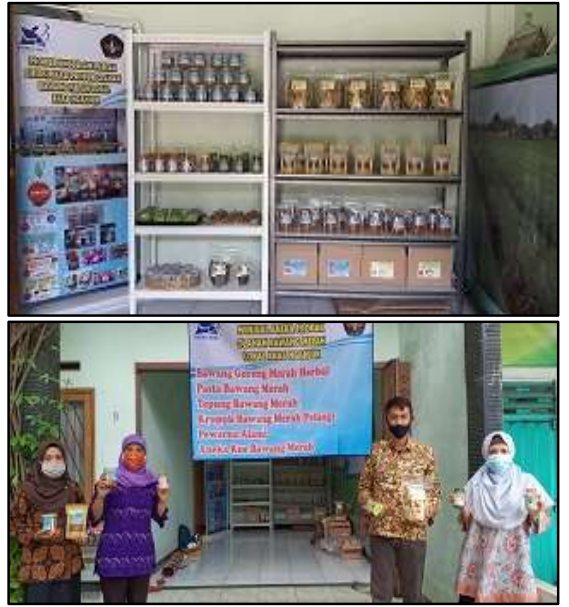

Gambar 8. Outlet Pemasaran hasil olahan bawang merah beserta tim pelkasana

Dari hasil yang telah diuraikan diatas maka berdasarkan analisa data-data selama pelaksanaan pada tahun pertama dan tahun kedua dapat ditunjukkan pada grafik berikut:

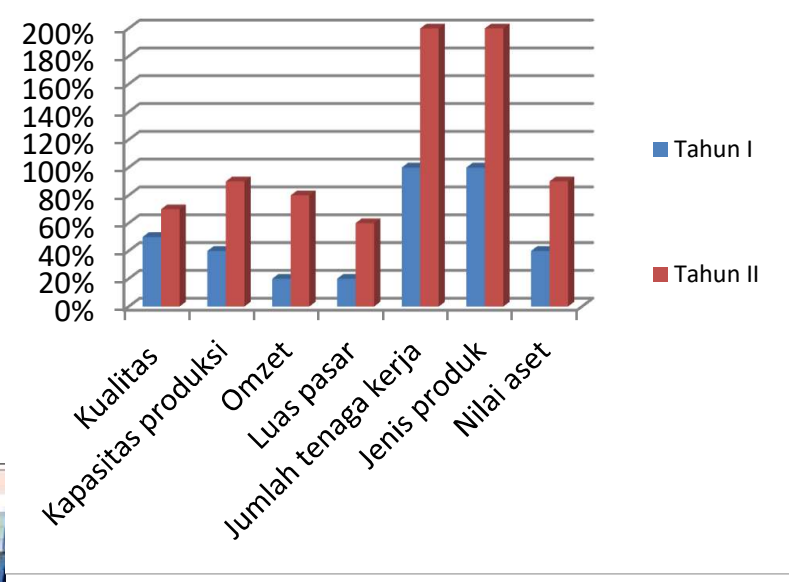

Gambar 9. Grafik peningkatan hasil pelaksanaan pada tahun 1 dan tahun ke-2 PPUD bawang Merah

Dari gambar 9 menjelaskan bahwa terdapat peningkatan pada beebrapa poin pelaksanaan output kegiatan, dimana terdapat peningkatan kualitas produk sebesar $70 \%$, peningkatan kapasitas produksi sebesar $90 \%$, peningkatan Omzet $80 \%$, peningkatan luas pasar $60 \%$, peningkatan jumlah tenaga kerja $200 \%$, peningkatan jenis produk $200 \%$, peningkatan nilai aset $90 \%$. Berikut peningkatan jenis produk diversifikasi yang baru dihasilkan ditahun ke-2 PPUD bawang merah ditahun kedua yang ditunjukkan pada gambar 10 (aroma/parfume bawang), sedangkan gambar 11 hasil diversifikasi dari bawang merah menjadi olahan Roti berbahan abon bawang, serta kue berbahan aroma bawang, 
sebagaimana ditunjukkan pada gambar dibawah ini.

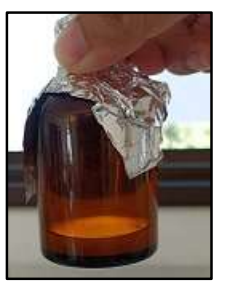

Gambar 10. Hasil olahan bawang merah berupa aroma/parfume bawang merah

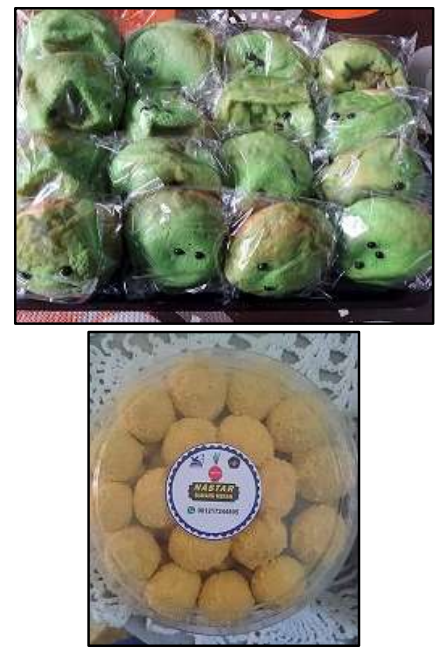

Gambar 11. Hasil olahan bawang merah berupa Roti Isi abon bawang dan kue beraroma bawang merah

\section{SIMPULAN DAN SARAN}

Simpulan

Kegiatan pengabdian kepada masyarakat di Desa Ngrami Kecamatan Sukomoro Kabupaten Nganjuk yang memasuki tahun ke 2 dengan dana hibah Ristek-Brin Program Pengembangan Produk Unggulan Daerah (PPPUD). Pada tahun ke-2 kegiatan ini dititik beratkan pada peningkatan produksi, peningkatan pemasaran, serta diversifikasi hasil olahan lain.

Peningkatan produksi dengan menambah jumlah mesin pengolah serta pemasaran produk sudah meluas sampai wilayah Jawa Timur, namun Sehingga terdapat peningkatan pada di beberapa indikator output kegiatan, dimana meningkatnya kualitas produk sebesar 70\%, meningkatnya kapasitas produksi sebesar 90\%, meningkatnya Omzet $80 \%$, meningkatnya luas pasar $60 \%$, meningkatnya jumlah tenaga kerja $200 \%$, meningkatnya jenis produk 200\%, meningkatnya nilai aset $90 \%$. Berikut peningkatan jenis produk diversifikasi yang baru dihasilkan ditahun ke-2 PPUD bawang merah diantaranya aroma/parfume bawang, roti berbahan abon bawang, serta kue berbahan aroma bawang,.

Saran

Kegiatan selanjutnya akan dikembangkan produk unggulan daerah olahan bawang merah varian lain seperti parfum bawang merah, suplemen bawang merah, camilan bawang merah, dll. dengan bahan baku yang berasal dari Bawang Merah Lokal Nganjuk. Diperlukan Tekonologi pengolahan untuk membuat produk bawang merah seperti parfum bawang merah dan suplemen bawang merah.

\section{DAFTAR PUSTAKA}

Arfinanti Nurul, 2019, Upaya peningkatan Nilai Tambah produk Bawang Merah, APLIKASIA, Vol.19 No.1, eISSN.2598-2176

Farid R. Abadi, 2019, Meningkatkan Nilai Tambah Bawang merah http://sulut.litbang.go.id/index.php/106infoteknologi4/790-apa-nama-umumbawangmerah.

Fauziyah, Handayani, Susanto, Rosanti, 2019, Aneka Produk Olahan Bawan Merah, Penerbit Indomedia Pustaka.

Fauziyah, Handayani, Susanto, Rosanti, 2019, Pengolahan Produk unggulan Daerah Bawang Merah Lokal di Kecamatan Sukomoro Kabupaten Nganjuk, ABDI vol.5 No.2 Januari 2020, Universitas Negeri Surabaya

Fauziyah, Handayani, Susanto, Rosanti, 2020, Diversitas Produk Unggulan Daerah Bawang Merah Lokal khas nganjuk untuk meningkatkan UMKM, Vol. 5 No. 1, 2020, Universitas PGRI Ronggolawe Jombang

Indrawati E.M., dkk, 2020, Pelatihan Pengolahan Bawang dengan Alat Pebmo Pada Kelompok Petani Bawang Merah Desa Sekoto Kab. Kediri, ABDINUS, Vol.3 No.2, Maret 2020, Universitas Nusantara PGRI Kediri

Perdana Putra Z., dkk, 2018, Analisis Nilai Tambah Bawang Goreng pada UD. Safari Bawang Goreng di Kelurahan Kebun Tebeng Kota Bengkulu, AGROINDUSTRI, Mei 2018 Universitas Kahuripan Kediri 
Resmi, Sunarti, Arnold. 2017. Parfum Bawang Merah dan Aneka Produk Olahan Bawang Merah.Penerbit Andi. Yogyakarta.

Rukmana. 2018 Prospek Agribisnis Bawang Merah, Penerbit Andi, Yogyakarta.

Sulistyo, Agus, 2020, Kabid Tanaman Hortikultura, Dinas Pertanian Nganjuk, Radar Nganjuk, 20 Mei 2020.

Sushanty, Dyah, 2016, Liputan Dinas Pertanian Kabupaten Nganjuk, Radar Nganjuk.

Susanto REW, Maskuri, dkk, 2020, Penerapan Teknologi Pemotong Daun Bawang Merah di Kab. Nganjuk, SNAPAN, Oktober 2020 Universitas Kahuripan Kediri 